\title{
Reproductive biology of Cabot's Terns on Cardos Island, Santa Catarina, Brazil
}

\author{
Hélio Augusto Alves Fracasso ${ }^{1}$, Joaquim Olinto Branco ${ }^{2}$ \& Edison Barbieri ${ }^{3,4}$ \\ ${ }^{1}$ Laboratório de Virologia Clínica e Molecular, Instituto de Ciências Biomédicas II, \\ Universidade de São Paulo - USP, Sala 225, Av. Professor Lineu Prestes, 1374, CEP 05508-900, \\ Cidade Universitária, Butantã, SP, Brazil, e-mail: h_fracasso@hotmail.com \\ ${ }^{2}$ Centro de Ensino em Ciências Tecnológicas da Terra e do Mar, Universidade do Vale do Itajaí - UNIVALI, \\ CP 360, CEP 88301-970, Itajaí, SC, Brazil, e-mail: branco@univali.br \\ ${ }^{3}$ Instituto de Pesca APTA - SAA, CP 61, CEP 11990-000, Cananéia, SP, Brazil \\ ${ }^{4}$ Corresponding author: Edison Barbieri, e-mail: edisonbarbieri@yahoo.com.br
}

FRACASSO, H.A.A., BRANCO, J.O. \& BARBIERI, E. Reproductive biology of Cabot's Terns on Cardos Island, Santa Catarina, Brazil. Biota Neotrop. 11(3): http://www.biotaneotropica.org.br/v11n2/en/ abstract?article+bn01111022011

\begin{abstract}
Cabot's Terns Thalasseus acuflavidus (Latham, 1737) are widely distributed along the Atlantic coast of South America from the Caribbean Islands $\left(12^{\circ} \mathrm{S}\right)$ to the region of Porto Deseado, Argentina $\left(46^{\circ} \mathrm{S}\right)$. Daily observations were conducted on the Cardos Island during 2003, 2005 and 2006 to determine timing and nesting success, and the reproductive biology of the Cabot's Terns nesting there. The first adults arrived at the colony from 22 April to 15 May during the three years recorded; a total of 144 nests were recorded in 2003, 174 in 2005 and 50 in 2006. Observed incubation time was $24.1 \pm 0.35$ days, and mean egg size was $5.15 \pm 0.02 \mathrm{~cm}$ in length and $34.30 \pm 0.25 \mathrm{~g}$ in weight. Hatching success was lowest in 2003 and highest in 2006, with natural causes (such as nest abandonment, flooding, inter and intra-specific fight) being the main cause of loss. The first eggs hatched in July in 2003, and in June in 2005 and 2006. Overall nesting success was lowest (4.00\%) in 2006 and much higher (36.1\% and $27.01 \%$, respectively) in 2003 and 2005.
\end{abstract}

Keywords: breeding, Cabot's Terns, Brazil, conservation, reproductive success.

FRACASSO, H.A.A., BRANCO, J.O. \& BARBIERI, E. A biologia reprodutiva de na ilha dos Cardos, Florianópolis, SC, Brasil. Biota Neotrop. 11(3): http://www.biotaneotropica.org.br/v11n2/pt/ abstract?article+bn01111022011

Resumo: O trinta-réis-de-bando, Thalasseus acuflavidus (Latham, 1737) é amplamente distribuído na costa Atlântica da América do Sul, desde as Ilhas do Caribe $\left(12^{\circ} \mathrm{S}\right)$ até a região de Porto Deseado, Argentina $\left(46^{\circ} \mathrm{S}\right)$. Durante as temporadas reprodutivas de 2003, 2005 e 2006 foram realizadas incursões diárias entre os meses de abril a setembro na Ilha dos Cardos com o objetivo de caracterizar a biologia reprodutiva dessa espécie. Os primeiros adultos chegaram à colônia a partir de maio com o registro de 144 ninhos em 2003, 174 em 2005 e 50 em 2006. O comprimento, volume e tempo de incubação dos ovos foram em média $5,15 \pm 0,02 \mathrm{~cm}, 34,30 \pm 0,25 \mathrm{~cm}^{3} \mathrm{e}$ $24,1 \pm 0,35$ dias, respectivamente. O maior sucesso de incubação foi encontrado em 2006 e o menor em 2005, com as causas naturais sendo o principal fator de perdas. Os primeiros jovens eclodiram em julho em 2003 e junho em 2005 e 2006, sendo estimado o sucesso reprodutivo de 48.00, 29.94 e 5.00\%, respectivamente. Palavras-chave: reprodução, trinta-reis-de-bando, Brasil, conservação, sucesso reprodutivo. 


\section{Introduction}

Cabot's Terns Thalasseus acuflavidus (Latham, 1737) (Efe et al. 2009) are widely distributed on the Caribbean and Atlantic coasts of North and South America. Its range extends from the southern USA, in the Caribbean along the coasts of Colombia and Venezuela and in Surinam, Brazil and Uruguay as far south as Puerto Deseado in Argentina (Escalante 1973, Shealer 1999, Barbieri \& Paes 2008). Generally they form dense colonies, with nests located about $50 \mathrm{~cm}$ apart, and have a clutch size of only one egg, which may present one of three color patterns based on number/color of spots per egg (Efe et al. 2004, Branco 2003a).

The taxonomic status of genus Thalasseus has been controversial over the last century, mainly because several related species/subspecies share morphological characteristics and show variable overlap in distribution. Efe et al. (2009) propose that the appropriate taxonomic classification for the New World terns (acuflavidus/eurygnathus complex) should be Cabot's Tern Thalasseus acuflavidus and that for the Old World (Sandwich) tern should be Thalasseus sandvicensis, and that they be considered two distinct species.

Cabot's Terns nest collectively in colonies with the South American terns $S$. hirundinacea and the Royal Tern Thalasseus maximus all along the South American coast, have been recorded with S. hirundinacea on the Papagaios Island in Macaé (RJ) (Sick \& Leão 1965) and on the coasts of Espírito Santo (Efe et al. 2000), Rio de Janeiro (Alves et al. 2004), São Paulo (Campos et al. 2004), Paraná (Krul 2004), Santa Catarina (Soares \& Schiefler 1995, Branco 2003a, b) and with both in Uruguay (Lenzi et al. 2010) and Argentina (Yorio et al. 1994, Scolaro et al. 1996, Quintana \& Yorio 1997).

In Brazil this species has mainly been studied on the coast of São Paulo (Barbieri and Pinna 2007a), Espírito Santo (largest colonies found), Santa Catarina and Rio Grande do Sul, on rocky coastal islands or beaches, between the months of April and October (Efe et al. 2000). We have recorded observations in Santa Catarina on two mixed colonies of Cabot's and South American terns at Itacolomis (Penha) and the Cardos Islands (Florianópolis) since 2001.

Despite being widely distributed in South America and present in relatively large populations, little is known about the distribution and abundance of Cabot's Terns in Argentina (Duffy et al. 1988, Scolaro et al. 1996) and Brazil (Sick 1997, Soares \& Schiefler 1995, Efe et al. 2000, Branco 2003a, b, 2004). Cardos Island has provided a favorable habitat for Cabot's Tern's breeding since 2001 and this paper presents hitherto unpublished data on the reproductive biology of Cabot's Terns on Cardos Island, Santa Catarina, Brazil. This study attempts to characterize their reproductive biology, and contribute to knowledge on the distribution and abundance of adults, the laying and hatching periods, and their reproductive success at this site in Brazil.

\section{Methods}

We have recorded observations on two mixed colonies of Cabot's and South American terns in Santa Catarina at Itacolomis (Penha) and the Cardos Island (Florianópolis) since 2001. Daily observations were made on terns on Cardos island (27 $48^{\prime} 54^{\prime}$ ' $\mathrm{S}, 48^{\circ} 34^{\prime} 52^{\prime \prime}$ ' W; area of $1.5 \mathrm{~km}^{2}$ ), Florianópolis, Santa Catarina, Brazil (Figure 1), during three reproductive seasons (2003, 2005 and 2006) from April to September (totaling 63, 121 and 144 days and 315, 847 and 1440 hours of observation, respectively).

Using the number of adults and nests and the egg-laying period, the reproductive season was sub-divided into three stages: early (May 12 to July 04), middle (July 05 to August 11) and late (after August 12). During the daylight hours, data on adult numbers, arrival of

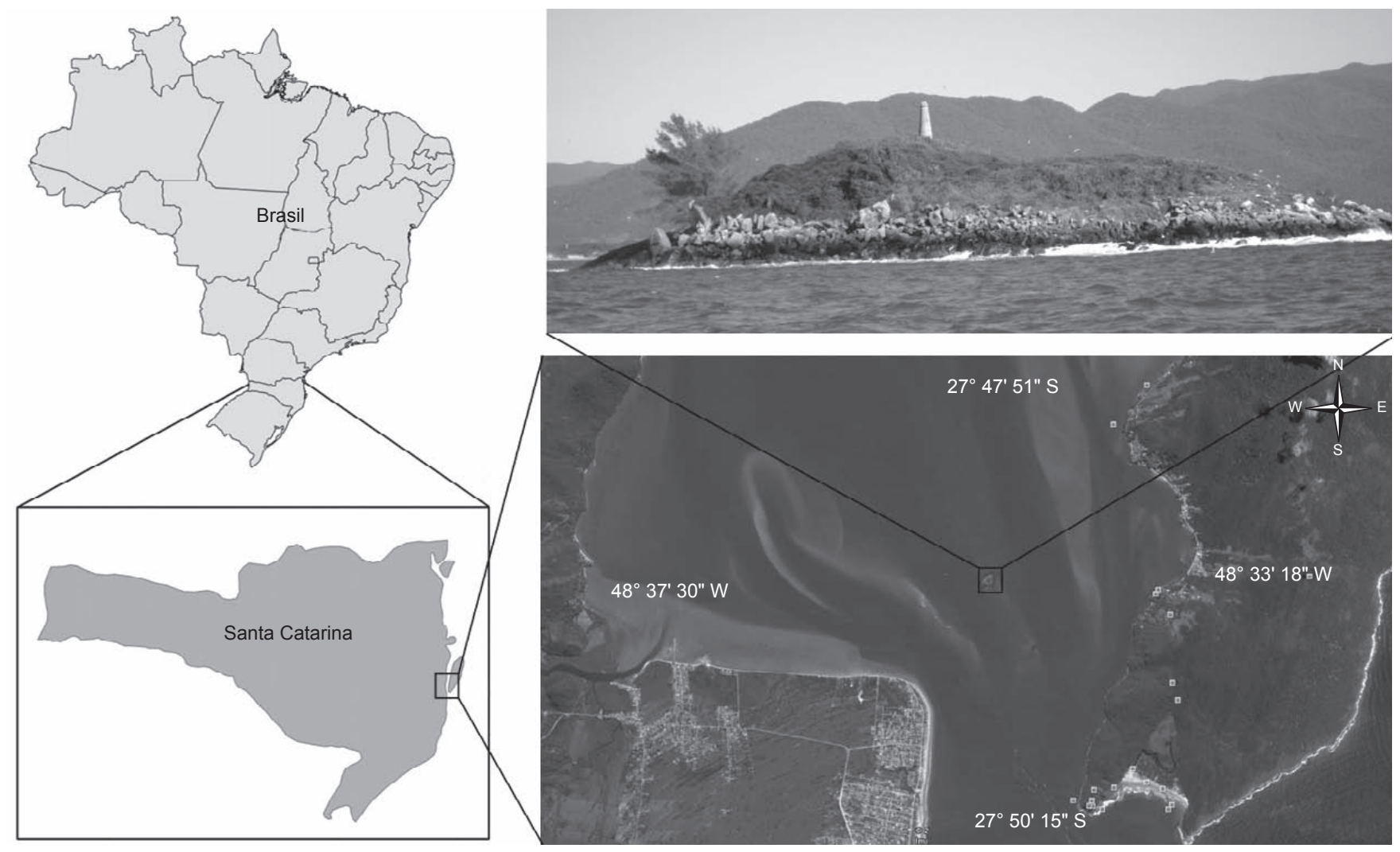

Figure 1. Map and overview of the study area, showing the location of Cardos Island in Brazil, and on the coast of the state of Santa Catarina. 
food, and chicks' delivery were obtained with binoculars $(10 \times 50$ Bushnell) and photography from a fixed point in the colony (Pereira 1997). In 2005 the adults arrived earlier than in 2003, data sampling being begun when the colony was fully developed.

\section{Eggs and laying}

The numbers of nests built, eggs laid, distance between nests (eggs to eggs to $0.1 \mathrm{~cm}$ ), number of chicks hatched and eggs lost were recorded. The length of the major axis of eggs ( $\mathrm{Lt})$ and width (WID) were determined with a caliper $(0.1 \mathrm{~cm})$ and mass $(\mathrm{Wt})$ with a dynamometer type Pesola scale $60 \mathrm{~g}$ (to the nearest $0.5 \mathrm{~g}$ ). Egg volume was determined by the equation of Hoyt (1979): Vol $\left(\mathrm{cm}^{3}\right)=\mathrm{Kv} . L t . \mathrm{Wid}^{2}$ when $\mathrm{Kv}=\mathrm{V} / \mathrm{Lt} . \mathrm{Wid}^{2}$, where volume estimated $\mathrm{Kv}=$ coefficient of $0.5205 ; \mathrm{Lt}=$ total length; $\mathrm{WID}=$ greater width of the axis.

All the eggs laid were counted in all the nests each year. Abandoned eggs, stillborn chicks, and predated eggs were removed daily to better quantify the daily losses due to natural causes and predators and estimate the hatching success.

\section{Chicks}

Chicks were counted by direct observation and recorded in accordance with their age and whether killed by natural causes, (such as lack of food, drowned by flooding and killed in parental territorial fights) or predation (hawks and vultures). Dead young were removed from the colony daily to prevent possible recounts, and a daily log of losses and causes was established. Records of numbers of all chicks present in the colony of each age class were kept for specific dates in all the years of the study from first hatch to colony dissolution.

Predators present or observed in acts of predation were identified by direct census or with binoculars, using the appropiate reference literature (Sick 1997).

Juvenile I (JI) corresponds to the nestlings generally found in the nests, with the egg tooth and average length of the beak of $1.42 \pm 0.04 \mathrm{~cm}$, of between 1 and 5 days. Juvenile II (JII), without the egg tooth with the leg sufficiently thick for the permanent metal ring, of 6 to 15 days, beak length of $1.77 \pm 0.09$. Juvenile III (JIII) with 16 to 30 days of life and an average beak length $=2.32 \pm 0.03$, remiges in/among the wing-feathers, tail feathers. Juvenile IV (JIV), with beak length of $2.68 \pm 0.12$, of 31 to 46 days. Only one juvenile $(\mathrm{J})$ was captured, with a beak of $3.1 \mathrm{~cm}$, leg of $2.6 \mathrm{~cm}$ and weight of $160 \mathrm{~g}$.

\section{Statistical Analyses}

Differences in distances between nests, and chicks' and eggs' biometry were examined using analysis of variance ANOVA, and tested for homogeneity of variance (Bartlett test) and normality of distribution (Kolmorov-Smirnov) (Zar 1999). The contrast of means (Tukey-Kramer test) was used to indicate which means were significantly different.

\section{Results}

\section{Breeding chronology}

The reproductive season of 2003 began with the arrival of the first adults in mid-May, and the number of breeders gradually increased until June, followed by oscillations in breeding pair numbers until the maximum number of nests was reached on July $22(\mathrm{~N}=115)$ and the site was abandoned in September in all the three years (Table 1). The formation of the colony in both 2005 and 2006 began in late April, with peak abundance in late May, on May $30(\mathrm{~N}=310)$ in 2005 and in early June, on June $07(\mathrm{~N}=100)$ in 2006 , followed by population declines until the abandonment of the colony in September (Table 1).

\section{Nest distances and clutch size}

Distance between nests (eggs to eggs), each with a clutch size of one egg, was almost exactly limited by the span of the birds' outstretched wings while on their nests $(0.58 \pm 0.19 \mathrm{~m})$. The lowest values were recorded in 2003, and were roughly $1 \mathrm{~cm}$ greater in 2005 and 2006 (Table 1), but no significant differences were found between years $\left(\mathrm{F}_{2-50}=1.69, P>0.05\right)$.

\section{Laying and egg size}

Only one reproductive peak was recorded during each breeding season, with the highest egg numbers reaching 144 for the colony in 2003, 174 in 2005 and 50 in 2006. Timing of highest number adults/ nest for the colony varied from late May to 30 July between the three years studied (Table 1).

The lowest and highest average lengths of eggs were recorded in 2005 and 2006, while the lowest and highest egg widths were observed in 2006 and 2005, respectively, and the lowest and highest egg masses occurred in 2003 and 2006, respectively (Table 1). There were no significant differences in length $\left(\mathrm{F}_{2-109}=1.71, P>0.05\right)$, width $\left(\mathrm{F}_{2-109}=0.57, P>0.05\right)$ or mass of eggs $\left(\mathrm{F}_{2-109}=0.03, P>0.05\right)$. There were no significant differences between the volumes of eggs $\left(34.30 \pm 0.25 \mathrm{~cm}^{3}\right)$ during the years of study $\left(\mathrm{F}_{2-109}=0.35, P>0.05\right)$, (Table 1).

\section{Hatching}

In 2003 we monitored six eggs from incubation to hatching, yielding an average $23.5 \pm 0.2$ days for hatching with a reduction in mass of $17.29 \%$ with an average daily decrease of $0.29 \mathrm{~g}$ (Figure 2). In 2005 , the average daily reduction of egg mass was $0.27 \mathrm{~g}(\mathrm{~N}=4)$, representing a decrease of $18.03 \%$, the mean incubation time for those 4 eggs being of $25.0 \pm 0.5$ days (Figure 2).

Of the 144, 174 and 50 eggs laid during the reproductive seasons of 2003, 2005 and 2006 (Table 1), respectively, 108, 157 and 41 of them hatched, yielding hatching success rates of $75.0 \%, 90.2 \%$ and $82.0 \%$ for 2003, 2005 and 2006, respectively. Daily loss of eggs by natural causes was lowest in 2003, while daily loss of eggs by predation that year was more than double that seen in 2005 (Table 2).

Table 1. Date of adults arrival at, peak and departure from the island, total number of nests ( $\mathrm{N}$ total), distance between them (in cm) and number of distances measured (N dist), Number (N), Length (Lt cm), Width (Wid cm), mass (Wt g) and volume (Vol $\mathrm{cm}$ ) of eggs of Thalasseus acuflavidus during the reproductive seasons of 2003, 2005, and 2006 on Cardos Island, SC, Brazil. (average \pm standard error).

\begin{tabular}{cccccccccccc}
\hline Year & \multicolumn{3}{c}{ Adults } & \multicolumn{3}{c}{ Nests/eggs } & \multicolumn{3}{c}{ Eggs } \\
\cline { 2 - 12 } & Arrival & Peak & Departure & N total & Distance cm & N dist & Lt cm & Width cm & Wt g & Vol cm & N \\
\hline 2003 & May, 15 & July, 30 & Sept, 27 & 144 & $0.5 \pm 0.03$ & 29 & $5.18 \pm 0.03$ & $3.62 \pm 0.02$ & $35.95 \pm 0.35$ & $34.6 \pm 0.4$ & 43 \\
2005 & April, 22 & May, 28 & Sept, 29 & 174 & $0.6 \pm 0.16$ & 6 & $5.12 \pm 0.02$ & $3.63 \pm 0.02$ & $35.98 \pm 0.41$ & $34.2 \pm 0.4$ & 48 \\
2006 & April, 27 & June, 07 & Sept, 30 & 50 & $0.6 \pm 0.7$ & 18 & $5.19 \pm 0.04$ & $3.60 \pm 0.02$ & $36.12 \pm 0.58$ & $34.1 \pm 0.6$ & 21 \\
\hline
\end{tabular}




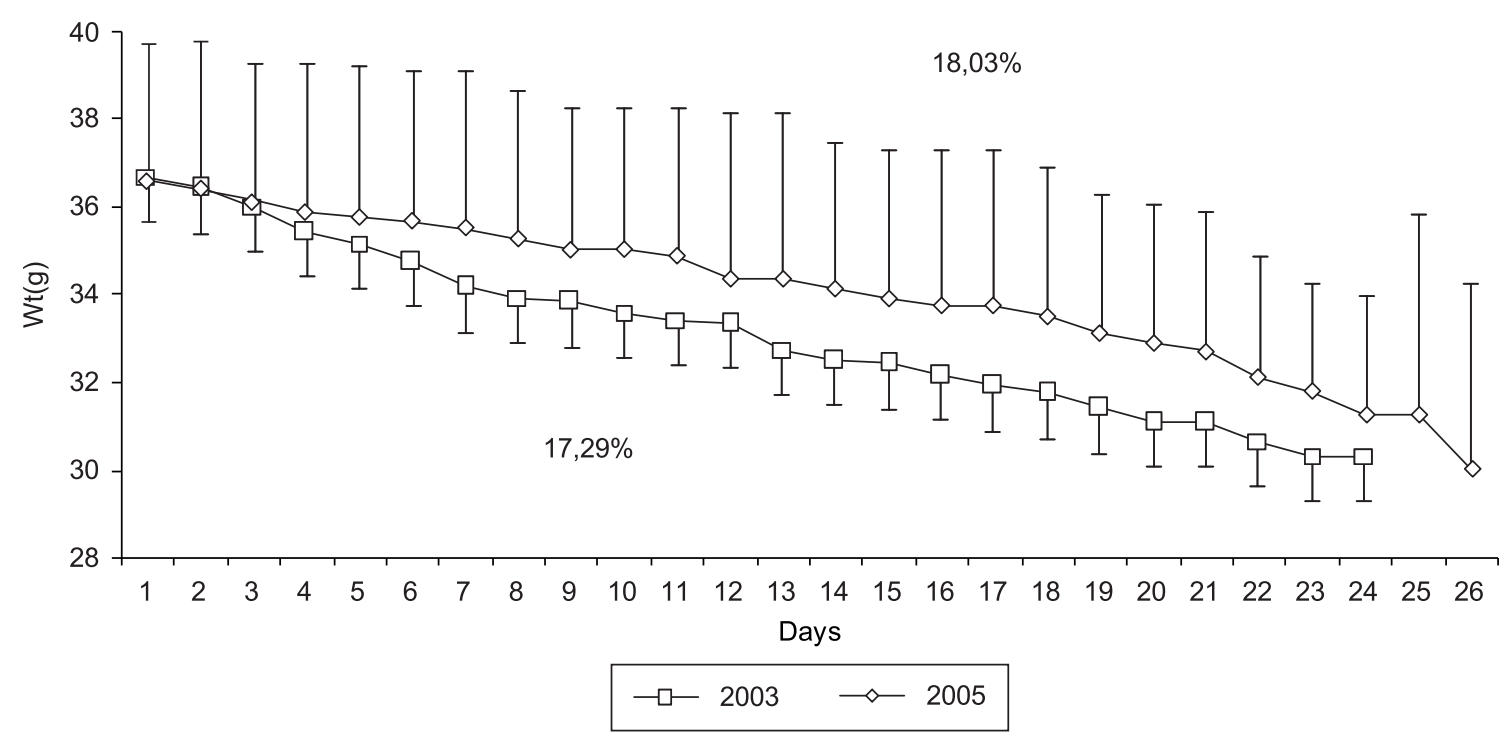

Figure 2. Average daily loss in the mass of Thalasseus acuflavidus eggs during the incubation periods in 2003 and 2005.

\section{Chicks}

In 2003, the first chick hatched on June 8 and the number gradually increased until July 21 when the greatest number of JI age class chicks were present in the colony $(\mathrm{N}=47)$. Hatching rates and the number of JI age class young present then declined continuously until the final chick matured to the JII age class by (or, on?) August 16 (Figure 3a). The same increasing and decreasing trend was found for each subsequent older age class as the hatching young matured, with highest values for JII on July 25 ( $\mathrm{N}=40)$, JIII on July $30(\mathrm{~N}=32)$ and JIV on August $15(\mathrm{~N}=35)$. Juveniles $(\mathrm{J})$ first appeared around 30 days after the first hatching (July 29), the maximum number of nests being counted on August $27(\mathrm{~N}=30)$ and decreasing gradually until the abandonment of the colony in late September (Figure 3a).

In 2005 the first hatch was recorded on June 6 with the highest value for JI hatchlings occurring on June $22(\mathrm{~N}=66)$ and declining until the last one was recorded on July 17 (Figure 3b). The respective peak abundances were observed in the middle of the period: for JII on June $27(\mathrm{~N}=60)$ and JIII on July $05(\mathrm{~N}=55)$, and at the end of the period for JIV on July $12(\mathrm{~N}=41)$ and $\mathrm{J}$ on July $28(\mathrm{~N}=25)$ (Figure 3b).

In 2006, the first hatching was observed on June 07, with the JI peak on June 12 and the total absence of all JIs on June 28 (Figure 3c). The highest number of JIIs occurred on June $20(\mathrm{~N}=22)$, of JIIIs on June $26(\mathrm{~N}=22)$, of JIVs on July $02(\mathrm{~N}=16)$ with the juveniles showing oscillations in the middle $(\mathrm{N}=5)$ and at the end of the period $(\mathrm{N}=6)$, with gradual abandonment completed on September 03.

\section{Overall breeding success}

The main reason observed for chick death was "natural causes" at the beginning of the hatching period with a highest observed loss rate of $82.92 \%$ from this cause in 2006, of $47.13 \%$ in 2005 and of $33.33 \%$ in 2003 (Table 3).

Chicks were predated more intensively in the middle of the post hatching period in all the three years, with observed predation losses of chicks of $22.92 \%$ in 2005, $18.51 \%$ in 2003 and $12.19 \%$ in 2006 when there was a very high loss of young chicks by natural causes that almost certainly reduced the apparent effect of loss to predators.
Table 2. Total of Thalasseus acuflavidus eggs laid, loss by natural causes and predation, number of eggs surviving to hatching and hatching success for each study season during reproductive seasons on Cardos Island, SC, Brazil.

\begin{tabular}{crcccc}
\hline Year & N & Natural & Predation & Total & $\%$ \\
\hline 2003 & 144 & 6 & 30 & 36 & 75.0 \\
2005 & 174 & 14 & 3 & 17 & 90.2 \\
2006 & 50 & 6 & 3 & 9 & 82.0 \\
\hline
\end{tabular}

Table 3. Number of chicks of Thalasseus acuflavidus that hatched, number and percent of those who died from natural causes and by predation, and number surviving to fledging and overall nesting success rate for the colony during the reproductive seasons of 2003, 2005, and 2006 on Cardos Island, SC, Brazil.

\begin{tabular}{ccccccc}
\hline Year & Natural & \% & Predation & \% & Total & \% \\
\hline 2003 & 36 & 33.33 & 20 & 18.51 & 56 & 36.1 \\
2005 & 74 & 47.13 & 36 & 22.92 & 110 & 27.0 \\
2006 & 34 & 82.92 & 5 & 12.19 & 39 & 4.0 \\
\hline
\end{tabular}

The overall observed nesting success of Cabot's Terns on Cardos Island after loss of eggs and chicks was $36.1 \%$ for $2003,27.01 \%$ in 2005 and $4.00 \%$ in 2006 (Table 3).

\section{Discussion}

Based only on the records obtained over the last decade (Yorio et al. 1998a,b, Efe et al. 2000, Branco 2004) and on information of shifts in colony location among nearby nesting sites, the number of breeding sites is estimated at 24 for Cabot's Terns (11 in Brazil and 13 in Argentina, Yorio \& Efe 2008). Despite the extensive coastline of both countries, the breeding of both species is concentrated at only a small number of sites. In Brazil, for example, more than $80 \%$ of Cabot's Terns nest in any given year on two or three islands along the coast of the state of Espírito Santo (Escalvada, Itatiaia, and Branca islands). Other known colonies which nest along the coasts of Rio de Janeiro (Sick 1997, Alves et al. 2004), São Paulo (Campos et al. 2004, Barbieri \& Pinna 2007a,b), Paraná (Krull 2004) and Santa Catarina (Branco 2004) rarely exceed a few 
Reproductive biology of Cabot's Terns
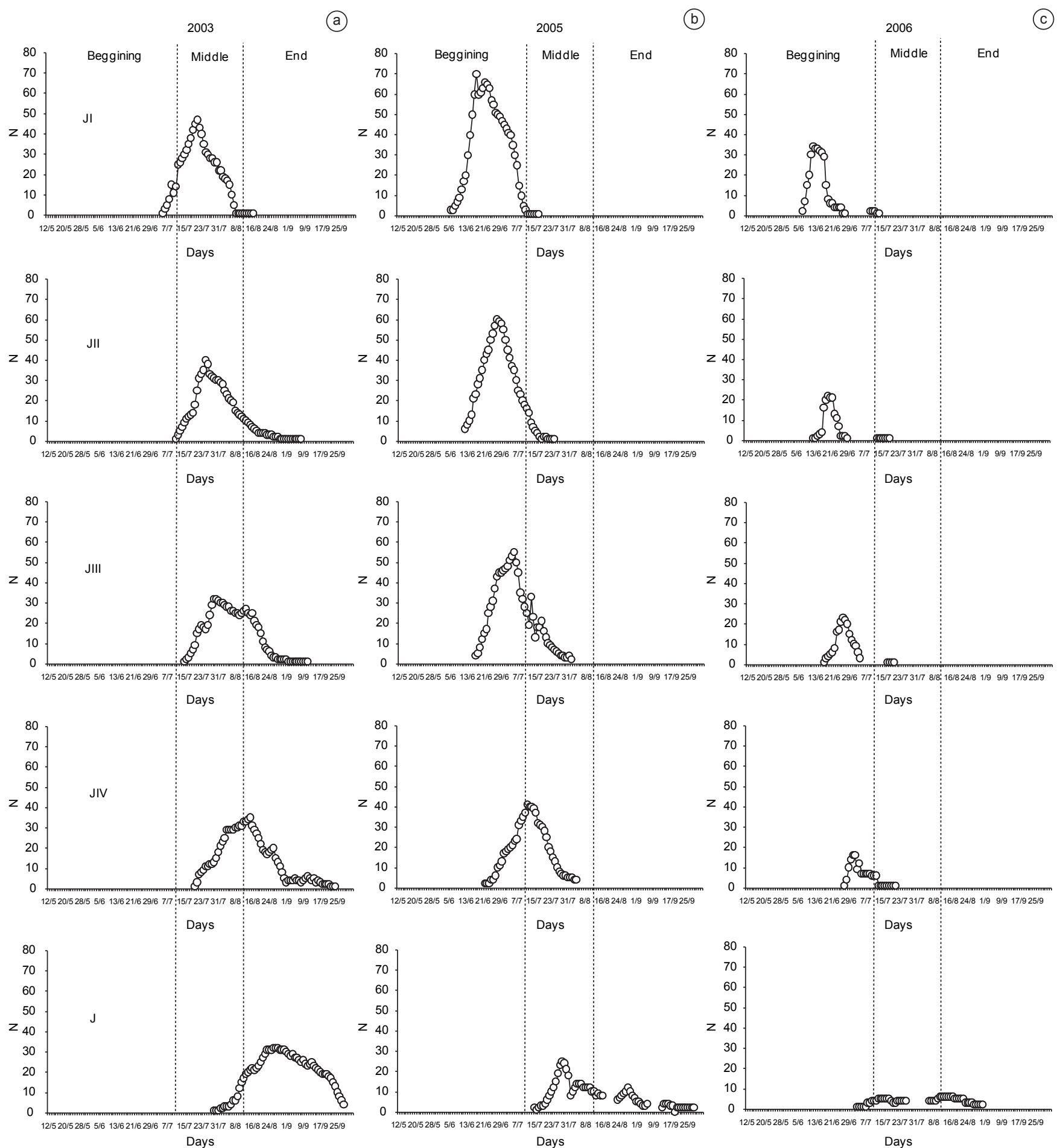

Figure 3. Daily variations in the number of newly hatched chicks age class I (JI), age II (JII), III (JIII), IV (JIV) and fledglings (age class J) of Thalasseus acuflavidus during the reproductive seasons of 2003 (a), 2005 (b) and 2006 (c) on Cardos Island, SC, Brazil.

hundred breeding pairs (Yorio \& Efe 2008). Similarly, in Argentina over $75 \%$ of Cabot's Terns nest in any given year at a few of ten potential breeding sites located at Punta León and in a small coastal sector in the north of Golfo San Jorge, Chubut (Yorio \& Efe 2008).

The reported reproductive period of Cabot's Terns on the Santa Catarina coast is May to October (Soares \& Schiefler 1995, Branco 2003a). Our research found timing similar to that described by
Efe et al. (2000) as from May to September on the islands of Espírito Santo, which differs from the period (March-October) cited for the coast of Rio de Janeiro (Sick and Leão 1965, Sick 1997), for the coast of Paraná (June to September - Krul 2004), for the coast of São Paulo (May to August - Campos et al. 2004), and for the coast of Argentina (November to February - Scolaro et al. 1996). Therefore, since the periods recorded, on the basis of systematic collection, for 
the northern and southern extremes of the species in Brazil coincide, it is believed that the different periods recorded for the intermediate breeding areas are due to the random nature of the data collection in these areas.

Cabot's Terns' nesting colonies occupy small areas with high concentrations of nests (Gochfeld and Burger 1996). On Cardos Island we found the average distance between nests was $0.5 \mathrm{~m}$ in an area of approximately 0.5 ha, while on Itaçuce island, on the São Paulo coast, with a 0.6 ha area and about 400 nests, reported distances corresponded to four nests $/ \mathrm{m}^{2}$ (Campos et al. 2004).

The egg-laying period in Argentina began in December and showed two peaks, in mid-December and early January, with late nests in late January (Scolaro et al. 1996). In Espírito Santo and Santa Catarina it began in May and peaked in June (Efe et al. 2000, Branco 2003b). Cabot's Terns only present a clutch size of one egg, whereas South American Terns have clutches of one to three and Roseate Terns Sterna dougalii of $2.27 \pm 0.18$ (Hébert 1985), and Common Terns Sterna hirundo may have up to six eggs/nest, with $2.6 \pm 0.3$ as mean clutch size (Buckley \& Buckley 1982).

The average hatching time of South American Terns in Argentina was 21.5 days (Scolaro et al. 1996), in Santa Catarina 21-24 (Branco 2003b), while Cabot's Terns from Espírito Santo averaged 23 days (range 19-26) (Efe 2004), corroborating the hatching time we recorded for the small sample in our study. Many factors, such as variation in atmospheric temperature and both the direct and indirect action of predators, may change the incubation time (Nisbet \& Welton 1984, Hébert 1985).

The reported hatching success of Cabot's Terns (Branco 2003b) in colonies in Argentina, 73.4\% in Punta Loma (Scolaro et al. 1996) and $45.3 \%$ in the colony of Punta Leon (Yorio et al. 1994), was lower than that recorded by Efe et al. (2005) on the coast of Espírito Santo $(80 \%)$. Failure of eggs to hatch in Punta Loma was attributed to predation (12.6\%) and desertion (14\%) (Scolaro et al. 1996). On the Santa Catarina coast, the removal of eggs by fishermen and tourists was one reported factor (Bege \& Pauli 1988, Sick 1977, Soares \& Schiefler 1995). Constant predation by Kelp gulls was reported by Branco (2003b). In our study, hatching success varied from 75-90.2\% with a mean of $80.43 \%$ over the three years due to hawk, vulture and lizard predation and losses due to natural and human disturbances in the colonies.

On the coast of Espírito Santo the first Cabot's Tern hatching was reported to occur in early July (Efe 2004), and that on Cardos Island in 2002 between 20 and 25 May, with a gradual increase from June to a peak in September (Branco 2003b). According to this present study, the presence of chicks was recorded from early June, with the highest abundance in July. This timing may have been facilitated by favorable climatic conditions and rapid laying, hatching and growth due to the high availability of food for nesting terns with little harassment from predators.

Most chick mortality within this genus occurs in the first week after hatching (Nisbet and Cohen 1975) and the average age of death of Sterna dougalli is from 3.3 to 4.0 days (Nisbet 1978, Spendelow 1982). Sterna hirundo breeding in Massachusetts reportedly fed up to three chicks per pair, and it was estimated that productivity was roughly 2.5 chicks per pair, the highest values reported for the species (Nisbet et al. 1984). Efe et al. (2005) found a high mortality rate during the first 7 days of life in Espírito Santo. On Cardos Island (present paper) only one chick was ever observed to be raised by any pair of Cabot's Terns.

The reported reproductive success of South American Terns on the Argentinian coast was $35.1 \%$ and chick mortality during the period was $52.2 \%$ (Scolaro et al. 1996). S. hirundinacea, T. acuflavidus and T. maximus on the Rio de Janeiro, São Paulo and Paraná coasts, had low reproductive success, reportedly stemming from nesting together with Kelp gulls L. dominicanus (Sick \& Leão 1965, Efe et al. 2000, Krul 2004, Alves et al. 2004, Branco et al. 2009). Other factors reported to contribute to the low reproductive success of this species were: activity of fishermen on the island overnight, and death of chicks that were cast into the sea when their nests were disturbed (Campos et al. 2004). On Santa Catarina Island, Branco (2003b) reported reproductive success of between $34.1 \%$ and $24.5 \%$, despite the predation pressure of hawks and Kelp gulls. In our study, we found that reproductive success was comparable, with $36.1 \%$ and $27.01 \%$ for 2003 and 2005, respectively, though much lower in 2006 when it was only $4.0 \%$.

Deserta Island (SC) does not suffer any major direct anthropogenic influence as it is within the Marine Biological Reserve of Arvoredo, a Federal Conservation Unit established in 1990. However, in the seasons of 2000 and 2002 the nesting population of Cabot's and South American Terns abandoned the island due to the strong predatory action of Kelp gulls (Branco 2003a). The low human pressure on Itacolomis and Cardos Island and the slight activity of natural predators during the laying and hatching period, and the constant supply of food from the sea-bob shrimp by-catch (Branco 2001), allowed the regular occupation of these nesting sites and contributed to good reproductive performance, making them important sites for the conservation of the species.

Despite the fact that Cabot's Terns breed in five Brazilian states, few ornithologists have studied: their reproductive biology to update and improve population estimates, evaluate factors determining changes in colony sites, analyze genetic structure and enhance knowledge of tern feeding ecology; the negative impact of Kelp Gulls on terns, or a possible increase in the protection of tern breeding populations through the designation of new marine protected areas (Yorio \& Efe 2008). We have attempted to address some of these issues and recommendations with our study on Cardos Island using our daily sample format to learn more about Cabot's Terns on the Santa Catarina coast. We would recommend vehemently/insistently that visits by fishermen and others to the island during the months of April and May be curtailed and that efforts be made to increase the legal protection of the island so as to conserve these tern species during their critical nesting time.

\section{Acknowledgements}

We wish to thank the Brazilian Research Council for Scientific and Technological Development (CNPq) who funded the Ph.D. student Hélio Augusto Alves Fracasso and provided productivity funds for J. O. Branco and J. R. Verani, and the Projeto Aves Marinhas for their logistic support. We would also thank the Foundation on the Environment of Santa Catarina - FATMA which granted the authorizations to work on the island of Cardos and IBAMA (CEMAVE) for granting all the necessary licenses to work with birds. We would further thank our colleagues and trainees: Cristiano L. Evangelista, Fernando K. Decker, Juliano C. Hillesheim, Felipe Freitas Jr., among others, for their valuable field assistance and sorting of the material. We appreciate the improvements in English usage made by Phil Whitford through the Association of Field Ornithologists' program of editorial assistance.

\section{References}

ALVES, V.S., SOARES, A.B.A. \& COUTO, G.S. 2004. Aves marinhas e aquáticas das ilhas do litoral do Estado do Rio de Janeiro. In Aves marinhas insulares brasileiras: bioecologia e conservação (J.O. Branco, ed.). Editora da UNIVALI, Itajaí, p.83-100. 
BARBIERI, E. \& PINNA, F.V. 2007a. Variação temporal do Trinta-réis-debico-amarelo (Thalasseus sandvicensis eurygnatha) durante o ano de 2005 no estuário de Cananéia-Iguape-Ilha Comprida. Ornitol. Neotrop. 18:563-572.

BARBIERI, E. \& PINNA, F.V. 2007b. Distribuição do Trinta-reis-real (Thalasseus maximus) durante 2005 no estuário de Cananéia-Iguape-Ilha Comprida. Ornitol. Neotrop. 18:99-110.

BARBIERI, E. \& PAES, E.T. 2008. The birds at Ilha Comprida beach (São Paulo state, Brazil): a multivariate approach. Biota Neotrop. 8(3): http:// www.biotaneotropica.org.br/v8n3/en/abstract?article+bn00408032008.

BEGE, L.A.R. \&. PAULI, B.T. 1988. As aves nas Ilhas Moleques do Sul Santa Catarina: Aspectos da ecologia, etologia e anilhamento de aves marinhas. FATMA, Florianópolis.

BRANCO, J.O. 2001. Descartes da pesca do camarão sete-barbas como fonte de alimento para aves marinhas. Rev. Brasil. Zool. 18:293-300.

BRANCO, J.O. 2003a. Reprodução das aves marinhas nas ilhas costeiras de Santa Catarina, Brasil. Rev. Brasil. Zool. 20:619-623.

BRANCO, J.O. 2003b. Reprodução de Sterna hirundinacea Lesson e S. eurygnatha Saunders (Aves, Laridae), no litoral de Santa Catarina, Brasil. Rev. Brasil. Zool. 20:655-659.

BRANCO, J.O. 2004. Aves marinhas das Ilhas de Santa Catarina. In Aves marinhas insulares brasileiras: bioecologia e conservação (J.O. Branco, ed.). Editora da UNIVALI, Itajaí, p.15-36

BRANCO, J.O., FRACASSO, H.A.A., BARBIERI, E. 2009. Breeding biology of the kelp gull (Larus dominicanus) at Santa Catarina coast, Brazil. Ornitol. Neotrop. 20:409-419.

BUCKLEY, F.G. \& BUCKLEY, P.A. 1982. Microenvironmental determinants of survival in salt marsh-nesting common terns. Colon. Waterbirds 5:3948. http://dx.doi.org/10.2307/1521031

CAMPOS, F.P., PALUDO, D., FARIA, P.J. \& MARTUSCELLI, P. 2004. Aves insulares marinhas, residentes e migratórias, do litoral do Estado de São Paulo. In Aves marinhas insulares brasileiras: bioecologia e conservação (J.O. Branco, ed.). Editora da UNIVALI, Itajaí, p.57-82.

DUFFY, D.C., RYAN, P.G., WILSON, R.P. \& WILSON, M.P. 1988. Spring seabird distribution in the Strait of Magellan. Cormorant 16:98-102.

EFE, M.A. 2004. Aves marinhas das ilhas do Espírito Santo. In Aves marinhas insulares brasileiras: bioecologia e conservação (J.O. Branco, ed.). Editora da UNIVALI, Itajaí, p.101-118

EFE, M, A., MUSSO, C. \& GLOCK, L. 2005. Sucesso Reprodutivo de Thalasseus sandvicensis eurygnathus no Brasil. Biociências 13:63-68.

EFE, M.A., NASCIMENTO, J.L.X., NASCIMENTO, I.L.S. \& MUSSO, C. 2000. Distribuição e ecologia reprodutiva de Sterna sandivicensis eurygnatha no Brasil. Melopsittacus 3:110-121.

EFE, M.A., NASCIMENTO, J.L.X., NASCIMENTO, I.L.S., MUSSO, C. \& GLOCK, L. 2004. Variações Morfológicas e Padrões de Crescimento de Filhotes de Sterna sandvicensis eurygnatha no Brasil. Biociências 12:11-19.

EFE, M.A., TAVARES, E.S., BAKER, A.J. \& BONATTO, S.L. 2009. Multigene phylogeny and DNA barcoding indicate that the Sandwich tern Complex (Thalasseus sandvicensis, Laridae, Sternini) comprises two species. Mol. Phylogenetics Evol. 52:263-267. http://dx.doi. org/10.1016/j.ympev.2009.03.030

ESCALANTE, R. 1973. The Cayenne Tern in Brazil. Condor 75:470-472. http://dx.doi.org/10.2307/1366573

GOCHFELD, M. \& BURGER J. 1996. Family Sternidae (Terns). In Handbook of the birds of the world (J. Hoyo, A. Elliott \& J. Sargatal, eds.). Lynx Editions, Barcelona, v. 3: Hoatzin to Auks, p.624-667.

HÉBERT, P.N. 1985. Breeding failure and decline of a common tern colony in Southern Manitoba. Colon. Waterbirds 8:183-185. http://dx.doi. org/10.2307/1521070
HOYT, D.F. 1979. Practical methods of estimating volume and fresh weight of bird eggs. Auk 82:507-508.

KRUL, R. 2004. Aves marinhas costeiras do Paraná. In Aves marinhas insulares brasileiras: bioecologia e conservação (J.O. Branco, ed.). Editora da UNIVALI, Itajaí, p.37-56.

LENZI, J., JIMÉNEZ, S., CABALLERO-SADI, D., ALFARO, M. \& LAPORTA, P. 2010. Some aspects of the breeding biology of Royal (Thalasseus maximus) and Cayenne terns (T. sandvicensis eurygnathus) on Isla Verde, Uruguay. Ornitologia Neotropical 21:361-370.

NISBET, I.C.T. \& COHEN, M. E. 1975. Asynchronous hatching in Common and Roseate terns, Sterna hirundo and Sterna dougalli. Ibis 117:374-379. http://dx.doi.org/10.1111/j.1474-919X.1975.tb04225.x

NISBET, I.C.T. 1978. Dependence of fledging success on egg-size, parental performance and egg-composition among Common and Roseate Terns, Sterna hirundo and S. dougalli. Ibis 120:207-216. http://dx.doi. org/10.1111/j.1474-919X.1978.tb06777.x

NISBET, I.C.T. \& WELTON, M.J. 1984. Seasonal variations in breeding success of Common Terns: consequences of predation. Condor 86:53-60. http://dx.doi.org/10.2307/1521090

NISBET, I.C.T., WINCHELL, J.M. \& HEISE, A.E. 1984. Influence of age on the breeding biology of common terns. Colon. Waterbirds 7:117-126.

PEREIRA, J.M.C. 1997. Comparação da alimentação e crescimento de crias em duas espécies simpátricas de garajau (Sterna hirundo; Sterna dougallii) nos Açores. Relatório de Estágio do Curso de, Faro.

QUINTANA, F. \& YORIO, P. 1997. Breeding biology of Royal and Cayenne Terns at a mixed-species colony in Patagonia. Wilson Bull. 109:650-662.

SCOLARO, J.A., LAURENTI, S. \& GALLELLI, H. 1996. The nesting and breeding biology of the South American Tern in northern Patagônia. J. Field Ornithol. 67:17-24.

SHEALER, D. 1999. The Birds of North America. The Birds of North America, Inc. Philadelphia, n. 405: Sandwich Tern (Sterna sandvicensis), p.566-572.

SICK, H. \& LEÃO, A.P. 1965. Breeding sites of Sterna eurygnatha and other sea birds of the Brazilian coast. Auk 82:507-508.

SICK, H. 1997. Ornitologia Brasileira. Nova Fronteira, Rio de Janeiro.

SOARES, M. \& SCHIEFLER, F. 1995. Aves da Ilhota da Galheta, Laguna, SC, Brasil. Arquiv. Biol. Tecnol. 38:1101-1107.

SPENDELOW, J.A. 1982. An analysis of temporal variation in, and the effects of habitat modification on, the reproductive success of Roseate Terns. Colon. Waterbirds 5:19-31. http://dx.doi.org/10.2307/1521029

YORIO, P. \& EFE, M.A. 2008. Population status of Royal and Cayenne Terns breeding in Argentina and Brazil. Waterbirds 31:561-570.

YORIO, P., QUINTANA, F., CAMPAGNA, C. \& HARRIS, G. 1994. Diversidad, abundancia y danimica espacio-temporal de la colonia mixta de aves marinas en Punta Leon, Patagonia. Ornitol. Neotrop. 6: 69-77.

YORIO, P., BERTELLOTTI, M., BORBOROGLU, P.G., CARRIBERO, A., GIACCARDI, M., LIZURUME, M.E., BOERSMA, D. \& QUINTANA, F. 1998a. Distribucíon reproductiva y abundancia de las aves marinas de Chubut. Parte I: de Península Valdés a Islas Blancas. In Atlas de la distribucíon reproductiva de aves marinas en el litoral Patagónico Argentino (P. Yorio, E. Frere, P. Gandini \& G. Harris, eds.). Instituto Salesiano de Artes Gráficas, Buenos Aires, p.39-73.

YORIO, P., BORBOROGLU, P.G., BERTELLOTTI, M., LIZURUME, M.E., GIACCARD, I.M., PUNTA, G., SARAVIA, J., HERRERA, G., SOLLAZZO, S. \& BOERSMA, D. 1998b. Distribución reproductiva y abundancia de las aves marinas de Chubut. Parte II: Norte del Golfo San Jorge, de Cabo Dos Bahías a Comodoro Rivadavia. In Atlas de la distribucíon reproductiva de aves marinas en el litoral Patagónico Argentino (P. Yorio, E. Frere, P. Gandini \& G. Harris, eds.). Instituto Salesiano de Artes Gráficas, Buenos Aires, p.76-117.

ZAR, J.H. 1999. Biostatistical Analysis. 4nd ed. Prentice-Hall Inc., New Jersey. 